\title{
Anurans from the Middle Jaguaribe River Region, Ceará State, Northeastern Brazil
}

\author{
Diego José Santana ${ }^{1,6}$, Sarah Mângia ${ }^{2}$, Ricardo Rodrigues da Silveira-Filho², Lívia Cláudia da Silva Barros ${ }^{3}$, \\ Igor Andrade ${ }^{3}$, Marcelo Felgueiras Napoli $^{4}$,Flora Juncá ${ }^{3}$ \& Adrian Antonio Garda ${ }^{5}$ \\ ${ }^{1}$ Universidade Federal de Mato Grosso do Sul, Centro de Ciências Biológicas e da Saúde, \\ Cidade Universitária, Campo Grande, MS, Brazil. \\ ${ }^{2}$ Universidade Federal da Paraíba, Departamento de Sistemática e Ecologia, João Pessoa, PB, Brazil. \\ ${ }^{3}$ Universidade Estadual de Feira de Santana, Departamento Ciências Biológicas, \\ Feira de Santana, BA, Brazil. \\ ${ }^{4}$ Universidade Federal da Bahia, Departamento de Zoologia, Instituto de Biologia, Salvador, BA, Brazil. \\ ${ }^{5}$ Universidade Federal do Rio Grande do Norte, Botânica e Zoologia, Campus Universitário, Lagoa Nova, \\ Natal, RN, Brazil. \\ ${ }^{6}$ Corresponding author: Diego José Santana, e-mail: jose.santana@ufms.br
}

SANTANA, D.J., MÂNGIA, S., SILVEIRA-FILHO, R.R., BARROS, L.C.S., ANDRADE, I., NAPOLI, M.F., JUNCÁ, F., GARDA, A.A. Anurans from the Middle Jaguaribe River Region, Ceará State, Northeastern Brazil. Biota Neotropica. 15(3): e20150017. dx.doi.org/10.1590/1676-06032015001715

\begin{abstract}
The Middle Jaguaribe River region is a poorly sampled area in the Caatingas domain, located in the eastern Ceará State, northeastern Brazil. The Brazilian government agencies considered this region as a priority area for conservation and inventories. In order to fill this biodiversity knowledge gap, we conducted a ten-day rapid inventory of the anuran fauna from April 11 to 20, 2014, surveying different physiognomies of the region. We recorded 19 anuran species belonging to five families: Bufonidae (2), Hylidae (5), Leptodactylidae (9), Microhylidae (2) and Odontophrynidae (1). Most inventories of Caatinga amphibians published to date have been conducted inside protected areas and/or of high altitude (mesic areas known as "brejos de altitude"). The list we present herein contributes to the knowledge of lowland Caatinga sites outside protected areas. We discuss our results in light of taxonomic and geographic features of the anurans sampled.
\end{abstract}

Keywords: Amphibians, Caatinga, semiarid, species list, biodiversity.

SANTANA, D.J., MÂNGIA, S., SILVEIRA-FILHO, R.R., BARROS, L.C.S., ANDRADE, I., NAPOLI, M.F., JUNCÁ, F., GARDA, A.A. Anuros da região do Médio Rio Jaguaribe, estado do Ceará, Nordeste do Brasil. Biota Neotropica. 15(3): e20150017. dx.doi.org/10.1590/1676-06032015001715

Resumo: A Região do Médio Rio Jaguaribe é uma área pobremente amostrada no domínio das Caatingas, localizada no leste do Estado do Ceará, Nordeste do Brasil. O Ministério do Meio Ambiente considera esta região como uma área prioritária para conservação e realização de inventários. Com o objetivo de preencher esta lacuna do conhecimento sobre a biodiversidade, nós conduzimos um inventário rápido da anurofauna de dez dias de 11 a 20 de Abril de 2014, amostrando diferentes fisionomias da região. Nós registramos 19 espécies de anfíbios anuros pertencentes a cinco famílias: Bufonidae (2), Hylidae (5), Leptodactylidae (9), Microhylidae (2) e Odontophrynidae (1). A maioria dos inventários de anfíbios na Caatinga publicados até o presente momento foram conduzidos em áreas de proteção e/ou de áreas de altitude (áreas mésicas conhecidas como "Brejos de Altitude"). A presente lista contribui para o conhecimento de áreas de baixada da Caatinga fora das áreas protegidas. Nós discutimos os resultados à luz de características taxonômicas e biogeográficas dos anuros amostrados.

Palavras-chave: Anfíbios, Caatinga, semiárido, lista de espécies, biodiversidade.

\section{Introduction}

The Caatingas morphoclimatic domain (Ab’Sáber 1977), despite being considered for a long time a low diversity region (Leal et al. 2003), has a high number of species for a semiarid region, and several endemic taxa (Albuquerque et al. 2012). This domain only occurs in the Brazilian territory, it is highly threatened by habitat loss and desertification (Tabarelli et al. 2003), and only $1 \%$ of its area is inside conservation units of integral protection (Leal et al. 2003). Furthermore, many places have been considered important for conservation based on meetings of scientists and policy makers, making such areas crucial for faunal inventories and future conservation efforts in the domain (e.g., MMA 2007, Melo et al. 2014). Some of these 
priority areas lie outside protected areas, and were selected based on several individual or combined parameters, such as the presence of endemic/endangered species, unique vegetation types or geomorphological formations, lack of biological knowledge, areas of endemism, and areas of high species richness (Tabarelli et al. 2003, Camardelli \& Napoli 2012). Such areas that are under agriculture and deforestation pressure may serve as connecting corridors between protected areas, and may harbor undescribed, endemic and/or rare species.

Data on the distribution, taxonomy, and natural history of amphibians of the Caatingas domain are incipient, and a large subset of the domain is still subsampled (Camardelli \& Napoli 2012, Borges-Leite et al. 2014). In addition, the effort for research in non-protected areas within the domain is quite inexpressive (e.g. Azarbe 1999, Vieira et al. 2007, Protázio et al. 2014). Only seven areas of the State of Ceará have published data on amphibian inventories (Borges-Nojosa \& Cascon 2005, Borges-Nojosa 2007, Borges-Nojosa et al. 2010, Loebmann \& Haddad 2010, Ribeiro et al. 2012, Borges-Leite et al. 2014), and most of these areas, despite being included within the Caatingas domain, do not harbour Caatinga vegetation sensu stricto (Ab'Sáber 2003), being in fact areas that are better characterized as Rain Forest and/or Cerrado enclaves, Coastal areas, or a mosaic of these.

Herein, we present the results of an amphibian survey conducted during the peak of the reproductive season in a Caatinga area in the Ceará State, northeastern Brazil. Our aim was to provide a list of amphibian species occurring in the area, making data available for conservation planning at the State and National levels.

\section{Material and Methods}

We conducted the fieldwork at the Middle Jaguaribe River region, Jaguaribe Municipality, eastern Ceará State (Figure 1). The Jaguaribe River Basin covers $72.440 \mathrm{Km}^{2}$ along $610 \mathrm{Km}$ in the Ceará State, with its head at the Serra da Joaninha (Tauá Municipality) and its mouth at the coast of Aracati Municipality (Souza \& Silva 2013). The study area is within the Caatingas morphoclimatic domain and it is characterized by typical Caatinga vegetation (Ab'Sáber 2003), containing physiognomies ranging from arboreal areas to open grass fields and rocky outcrops (Figure 2). Altitude ranged from 150 to $650 \mathrm{~m}$ above sea level, and local climate is Equatorial Savanna with dry winter (Aw) according Köppen-Geiger classification (Kottek et al. 2006). Mean annual temperature is $26.5^{\circ} \mathrm{C}$, while mean annual precipitation is $905 \mathrm{~mm}$ with most rainfall concentrated from February to May (INMET).

Animals were registered during diurnal and nocturnal visual surveys at four localities in the municipality region, from April $11^{\text {th }}$ to April $20^{\text {th }}, 2014$. We surveyed a wide variety of environments, including ponds, brooks, forest interior, temporary puddles, and other water bodies. These environments were sampled in four mainly sites in the Jaguaribe region: $1=\mathrm{Mr}$. Alzir farm (shrubby Caatinga in a sloped area near to the Serra dos Bastiões with presence of temporary streams, temporary ponds and a small dam), $2=$ Pond near to Santana's dam (permanent water body near to big dam within pastures and Caatinga fragments), $3=$ Serra do Barro Vermelho (hill with temporary streams and temporary ponds within a forested Caatinga), $4=\mathrm{Mr}$. Nogueirinha farm (a grassland area with shrubs spread in a Caatinga formation,

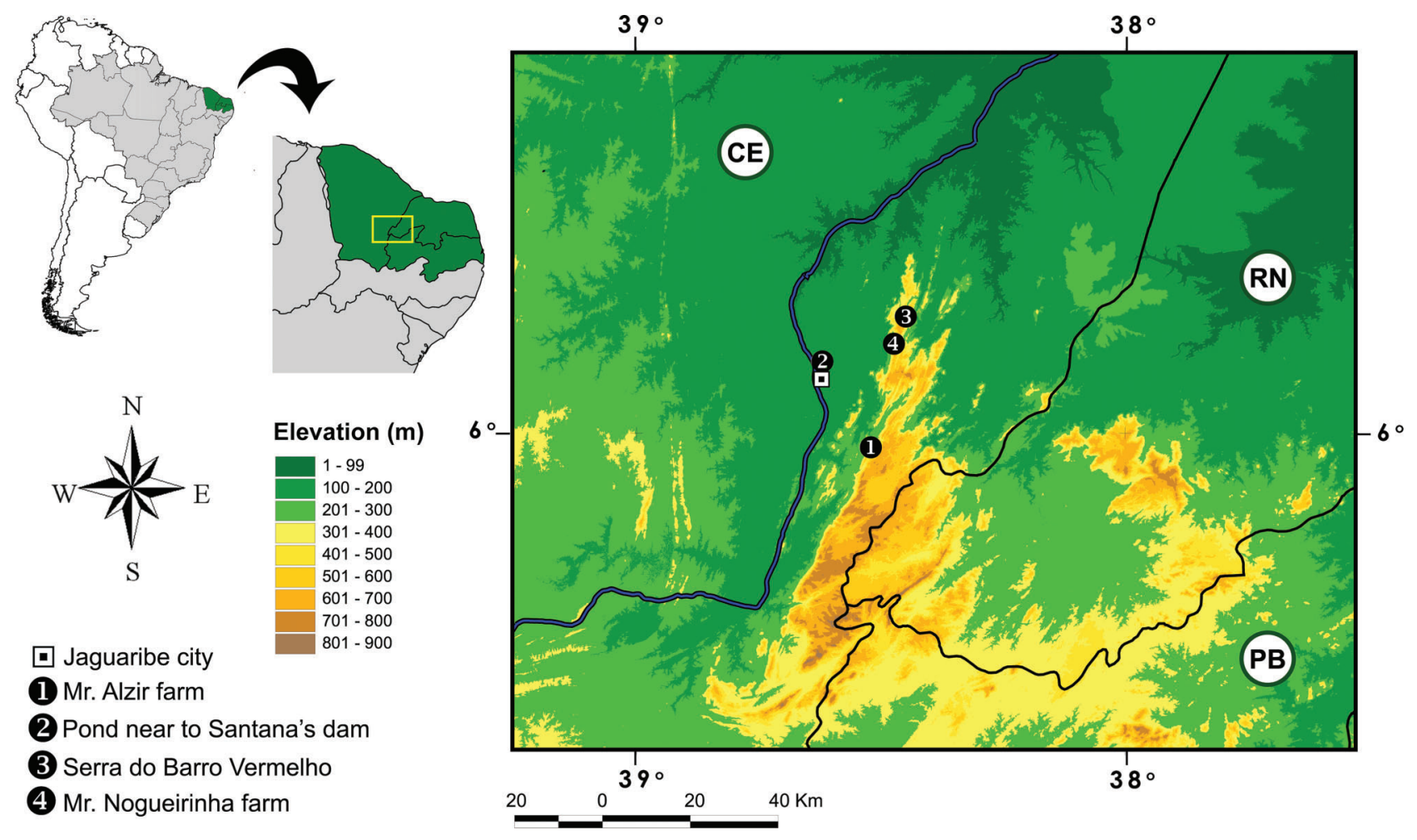

Figure 1. Map of the Region of the Middle Jaguaribe River. Survey sites: $1=$ Mr. Alzir Farm; $2=$ Pond Near to Santana Dam; $3=$ Serra do Barro Vermelho; 4 = Mr. Nogueirinha Farm; square = City of Jaguaribe $(\mathrm{CE}=$ State of Ceará; PB $=$ State of Paraíba; RN = State of Rio Grande do Norte). 


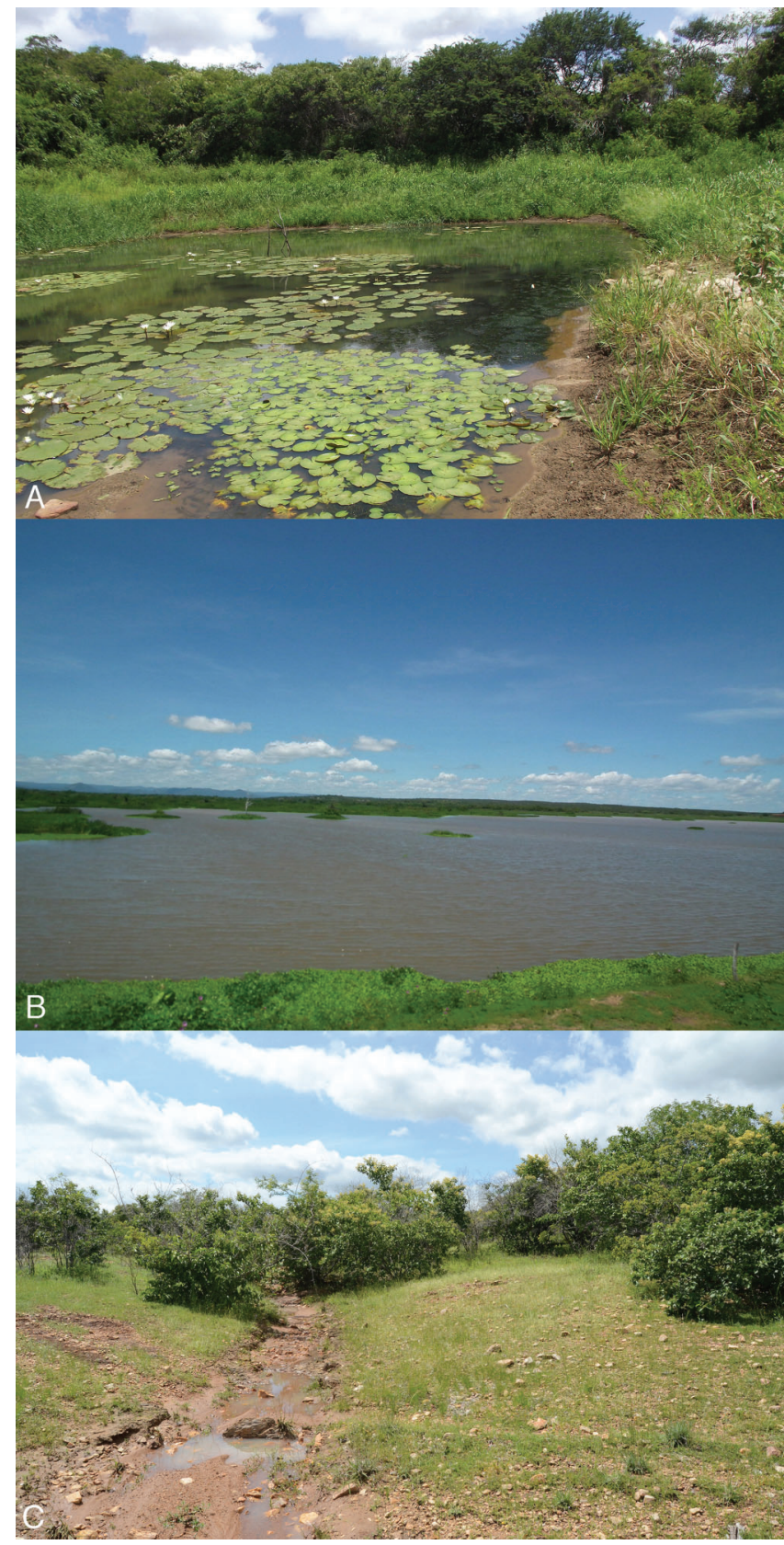

Figure 2. Landscapes in the Middle Jaguaribe River region, State of Ceará, northeastern Brazil, and some examples of sampled habitats: $\mathrm{A}=$ permanent pond in Serra do Barro Vermelho; B = Santana Dam near the survey site 2; $\mathrm{C}=$ temporary stream in a Caatinga area at $\mathrm{Mr}$. Alzir Farm.

and with small temporary ponds). Each study site was surveyed by at least five researches simultaneously. Our field inventory methods followed the "Complete Species Inventories", "Visual Encounter Surveys", and "Audio Strip Transects" guidelines of Heyer et al. (1994).

Voucher specimens are deposited in the herpetological collection of "Laboratório de Anfíbios e Répteis" at "Universidade Federal do Rio Grande do Norte" (AAGARDA), and "Museu de Zoologia" at "Universidade Estadual de Feira de Santana" (MZFS) (Appendix 1). Collected license was issued by Instituto Chico Mendes de Conservação da Biodiversidade - ICMBio (license number 19828).
We perform an accumulation curve by using the individualbased (Gotelli \& Colwell 2001), through 1000 randomizations of an abundance matrix where each column represents a species and each row represents one sampling site. We used species richness estimator Jacknife1 to determine the expected richness of amphibians (Colwell \& Coddington 1994, Colwell 2009). This analysis was performed using EstimateS v.9.0.0 (Gotelli \& Colwell 2001). We build graphs using Stata v.11 for Mac (@Stata Corp).

\section{Results and discussion}

We recorded nineteen anuran species in five families (Table 1, Figure 3) at the Middle Jaguaribe River region: Bufonidae (2), Hylidae (5), Leptodactylidae (9), Microhylidae (2) and Odontophrynidae (1). None of the recorded species is listed in the Brazilian list of endangered species or in IUCN red list (Brasil, 2014, 101 IUCN, 2014). In fact, most of them show wide geographic distributions and occur in two or more biomes (Ribeiro et al. 2012, Teixeira-Jr. et al. 2012, Magalhães et al. 2013, Magalhães et al. 2014, Cavalcanti et al. 2014, Silva et al. 2014).

Regarding the sampling effort, the accumulation curve tends to an asymptote after 267 individual sampled (Figure 4), with richness estimator Jacknife1 recovering 20 species. Despite the estimated richness based on the estimators suggesting one more species for the region, the sampling seems looks enough, reaching close its asymptote. Nevertheless, it is important to underscore that accumulation curves rarely stabilize, mainly in

Table 1. Anurans recorded at the Middle Jaguaribe River region, Ceará State, northeastern Brazil (period of sampling from April $11^{\text {th }}$ to April $\left.20^{\text {th }}, 2014\right)$.

\begin{tabular}{|c|c|}
\hline Family & Species \\
\hline \multirow[t]{2}{*}{ Bufonidae } & Rhinella granulosa (Spix, 1824) \\
\hline & Rhinella jimi (Stevaux, 2002) \\
\hline \multirow[t]{5}{*}{ Hylidae } & $\begin{array}{l}\text { Corythomantis greeningi (Boulenger, } \\
1896 \text { ) }\end{array}$ \\
\hline & Dendropsophus nanus (Boulenger, 1889) \\
\hline & Hypsiboas raniceps Cope, 1862 \\
\hline & Phyllomedusa nordestina Caramaschi, 2006 \\
\hline & Scinax $x$-signatus (Spix, 1824) \\
\hline \multirow[t]{11}{*}{ Leptodactylidae } & Leptodactylus fuscus (Schneider, 1799) \\
\hline & Leptodactylus macrosternum Miranda- \\
\hline & Ribeiro, 1926 \\
\hline & Leptodactylus troglodytes Lutz, 1926 \\
\hline & Leptodactylus vastus Lutz, 1930 \\
\hline & Physalaemus albifrons (Spix, 1824) \\
\hline & Physalaemus cicada Bokermann, 1966 \\
\hline & Physalaemus cuvieri Fitzinger, 1826 \\
\hline & Pleurodema diplolister (Peters, 1870) \\
\hline & Pseudopaludicola pocoto Magalhães, \\
\hline & $\begin{array}{l}\text { Loebmann, Kokubum, Haddad, and } \\
\text { Garda, } 2014\end{array}$ \\
\hline \multirow[t]{2}{*}{ Microhylidae } & Dermatonotus muelleri (Boettger, 1885) \\
\hline & $\begin{array}{l}\text { Elachistocleis piauiensis Caramaschi \& } \\
\text { Jim, } 1983\end{array}$ \\
\hline Odontophrynidae & Proceratophrys cristiceps (Müller, 1883) \\
\hline
\end{tabular}




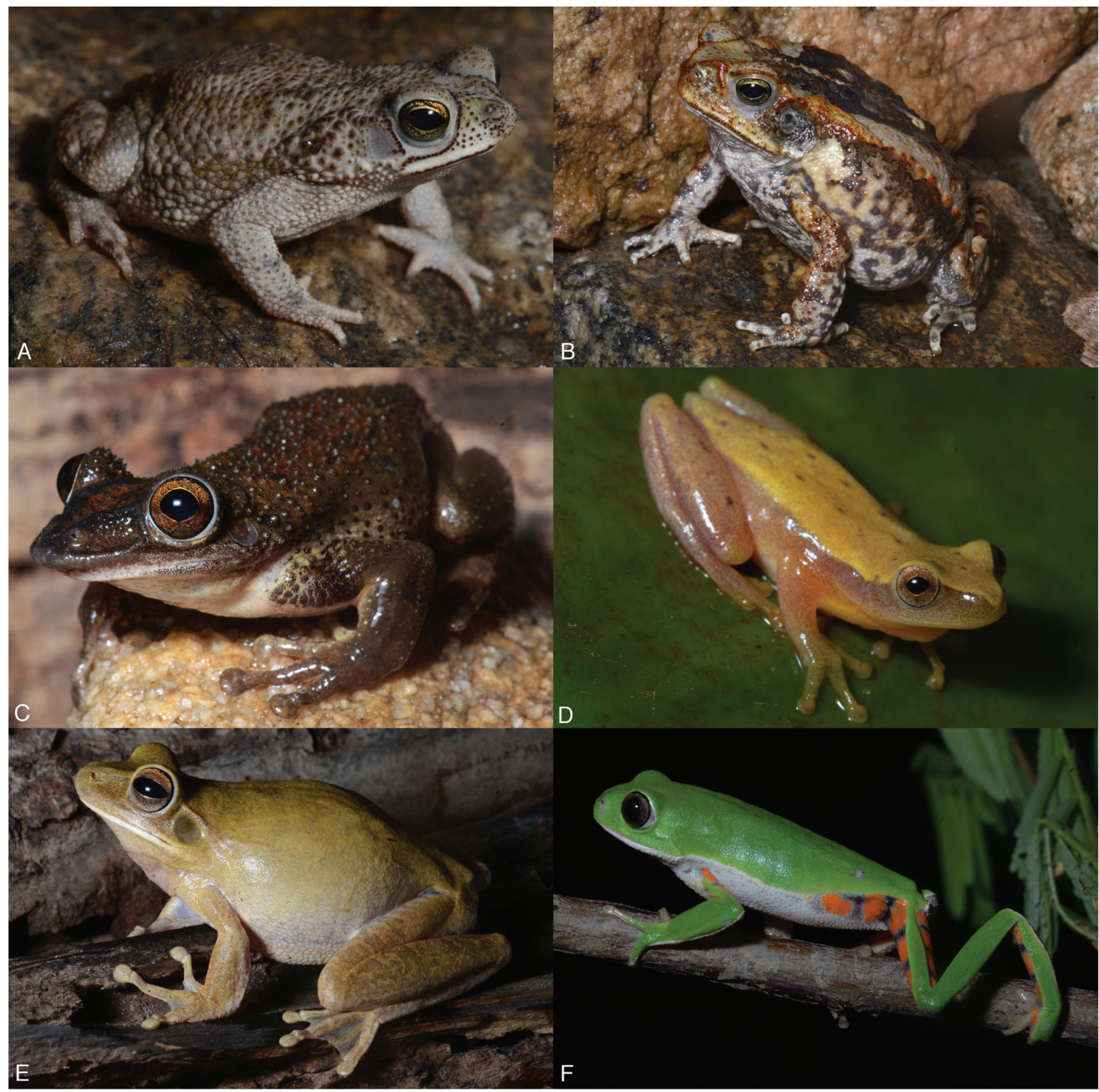

Figure 3. Anurans registered at the Middle Jaguaribe River region, Ceará State, northeastern Brazil: A = Rhinella granulosa (AAGARDA 10216); $\mathrm{B}=$ Rhinella jimi (AAGARDA 10292); $\mathrm{C}=$ Corythomantis greening (AAGARDA 10391); $\mathrm{D}=$ Dendropsophus nanus (AAGARDA 10276); $\mathrm{E}=$ Hypsiboas raniceps (AAGARDA 10404); F = Phyllomedusa nordestina (individual not collected).

tropical environments (Santos 2003). Although we carried our survey in the rainy season, some species of the Caatinga biome present explosive breeding behavior, coming out to breed few nights in a year (Duellman \& Trueb 1986, Wells 1977), and these species (e.g. Dermatonotus muelleri, Physalaemus cicada, Pleurodema diplolister and Proceratophrys cristiceps) depend of specific rainy events. Nevertheless, we have recorded such species considered explosive breeding or opportunistic (Protázio et al. 2014).

Literature data on frog assemblages in Caatinga are scarce, and most of the studies conducted inside protected areas and/ or at high altitude areas (Camardelli \& Napoli 2012). In the state of Ceará, only seven amphibian species lists have been published (Borges-Leite et al. 2014). Four studies in high altitude areas: Chapada do Araripe Bioregion (Ribeiro et al. 2012), the Ibiapaba plateau, (Loebmann \& Haddad 2010), Serra das Almas reserve (Borges-Nojosa \& Cascon 2005) which also sampled areas of the reserve located in the "depressão sertaneja" with Caatinga vegetation strictu sensu, and Serra do Baturité (Borges-Nojosa 2007). Three studies were conducted in the lowland coastal region of the Ceará State: one in São Gonçalo do Amarante Municipality (Borges-Leite et al. 2014), and one was simultaneously carried in two sites in Caucaia and Pacajus municipalities (Borges-Nojosa et al. 2010). However, 


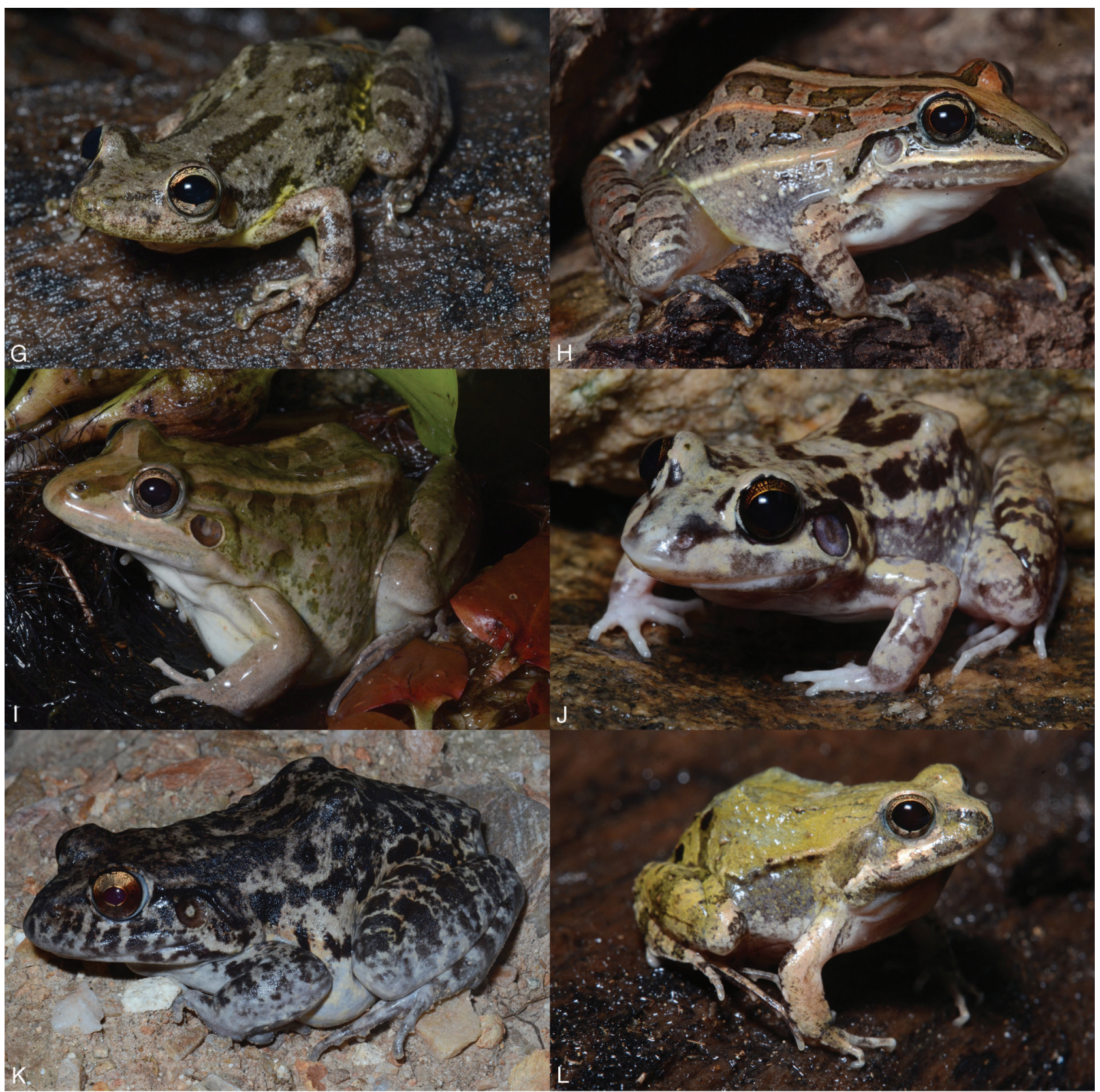

Figure 3 (continued). Anurans registered at the Middle Jaguaribe River region, Ceará State, northeastern Brazil: G = Scinax $x$ signatus (AAGARDA 10241); $\mathrm{H}=$ Leptodactylus fuscus (AAGARDA 10336); I = Leptodactylus macrosternum (AAGARDA 10188); J = Leptodactylus troglodytes (AAGARDA 10282); $\mathrm{K}=$ Leptodactylus vastus (AAGARDA 10339); L = Physalaemus albifrons (AAGARDA 10254).

these spots are located in the northeastern region of the Ceará State - the most impacted area in the state by human activities and also in close contact with coastal lowland regions.

Our inventory is the first study evaluating a nuclear area of the Caatingas domain in the Ceará State outside protected areas. All species sampled are present at least in one of the other seven species lists published for the state (Borges-Nojosa \& Cascon 2005, Borges-Nojosa 2007, Borges-Nojosa et al. 2010, Loebmann \& Haddad 2010, Ribeiro et al. 2012, Borges-Leite et al. 2014).

The species richness at the Jaguaribe Region (19 species) can be considered high for a semiarid sensu stricto Caatinga site. Betânia and Floresta sites in Pernambuco is the only another within Caatingas domain which have 19 species (Borges-Nojosa \& Santos 2005). The other studies performed in the Caatingas domain have 18 or less: Boa Vista (9), Cabaceiras (18), São João do Cariri (16) and São José do Bonfim (16) municipalities in state of Paraíba, and municipality of Jacobina (17) in state of Bahia (Arzabe 1999, Protázio et al. 2014, Vieira et al. 2007, Xavier and Napoli 2011). Considering this high richness and lack of protected areas in eastern Ceará State, the region is considered important for the conservation of Caatinga anuran species. 


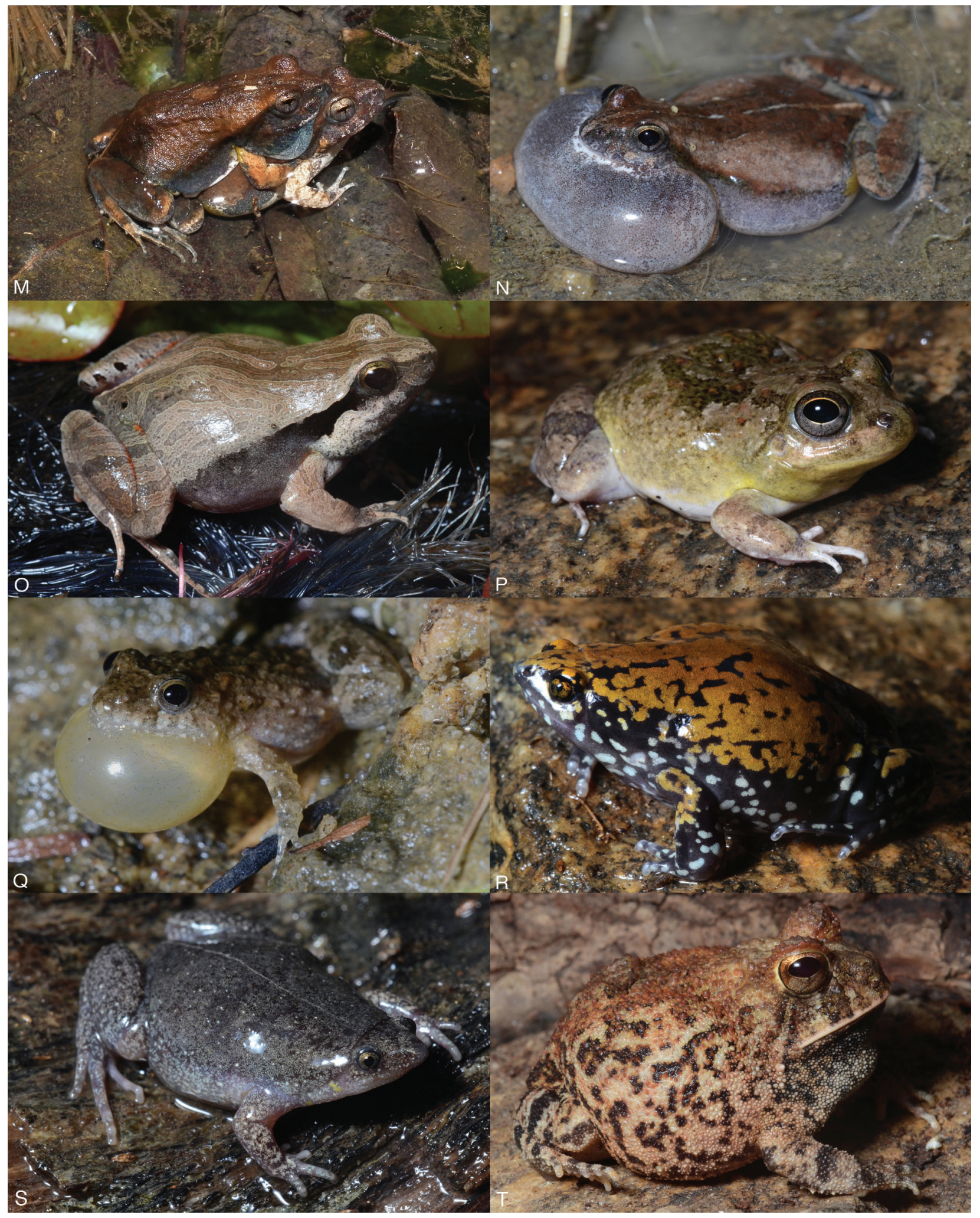

Figure 3 (continued). Anurans registered at the Middle Jaguaribe River Region, Ceará State, northeastern Brazil: M = couple of Physalaemus cicada (AAGARDA ); $\mathrm{N}=$ Physalaemus cicada (AAGARDA 10329); O = Physalaemus cuvieri (AAGARDA 10394); $\mathrm{P}=$ Pleurodema diplolister (AAGARDA 10349); $\mathrm{Q}=$ Pseudopaludicola pocoto (AAGARDA 10335); $\mathrm{R}=$ Dermatonotus muelleri (AAGARDA 10209). Anurans registered at the Middle Jaguaribe River region, Ceará State, northeastern Brazil: S = Elachistocleis piauiensis (AAGARDA 10251); T = Proceratophrys cristiceps (AAGARDA 10401). 


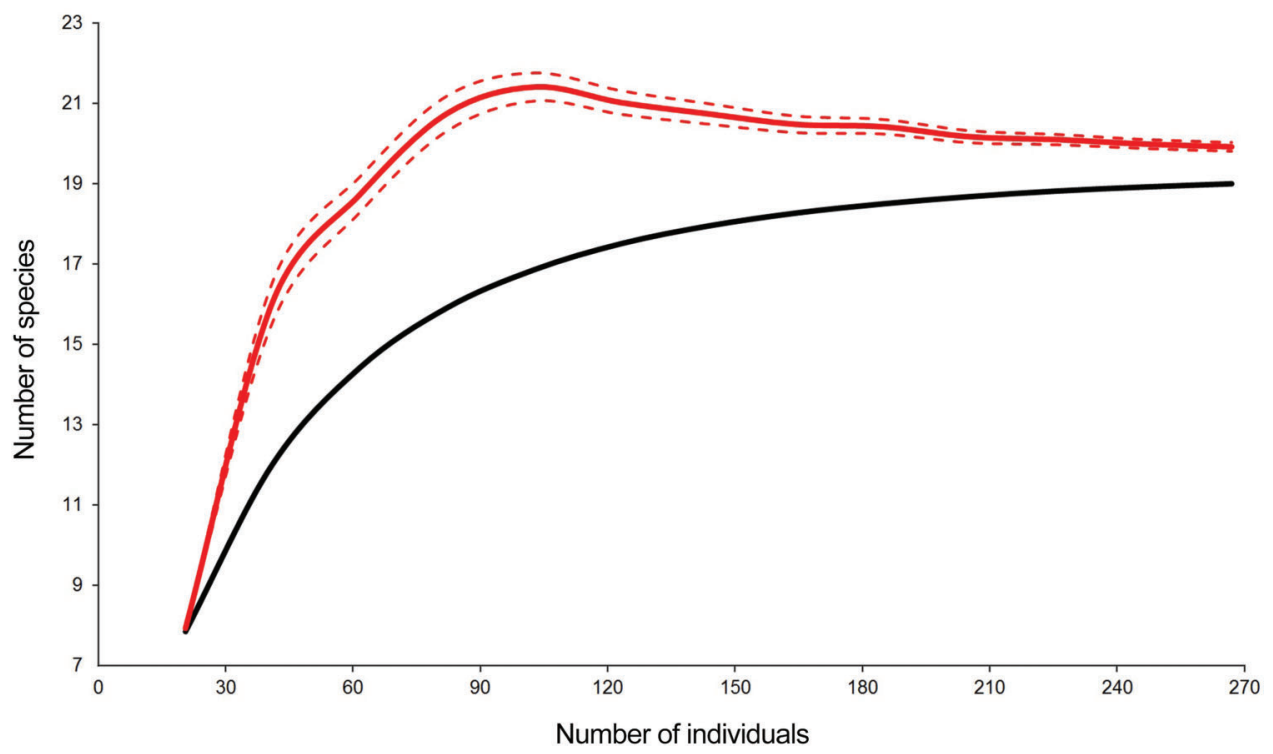

Figure 4. Accumulation curve for anurans sampled at the Middle Jaguaribe River region, Ceará State, northeastern Brazil (period of sampling from April $11^{\text {th }}$ to April 20 $\left.0^{\text {th }}, 2014\right)$. Black line represents the accumulation curves, red line represents species estimates based on Jacknife1 and red dashed lines represents its interval of confidence.

\section{Appendix 1. Voucher specimens of amphibians collected at Middle Jaguaribe River Region, Ceará State, Northeastern Brazil.}

Corythomantis greeningi - MZFS 4818-4822, AAGARDA 10174, AAGARDA 10289, AAGARDA 10391-10395; Dendropsophus nanus - MZFS 4806-4879, AAGARDA 1025910262, AAGARDA 10264, AAGARDA 10266, AAGARDA 10276, AAGARDA 10280, AAGARDA 10296; Dermatonotus muelleri - MZFS 4849, AAGARDA 10209; Elachistocleis piauienses - AAGARDA 10251; Hypsiboas raniceps AAGARDA 10269, AAGARDA 10404; Leptodactylus fuscus - MZFS 4823, AAGARDA 10336; Leptodactylus macrosternum MZFS 4809-4817, MZFS 4851, AAGARDA 10180, AAGARDA 10182-10183, AAGARDA 10186-10189, AAGARDA 10320, AAGARDA 10372-10374, AAGARDA 10403; Leptodactylus troglodytes - MZFS 4824-4825, AAGARDA 10282-10283; Leptodactylus vastus - AAGARDA 10270, AAGARDA 10319, AAGARDA 10339, AAGARDA 10347; Phyllomedusa nordestina - MZFS 4782-4801, AAGARDA 10210-10212, AAGARDA 10252, AAGARDA 10272-10275, AAGARDA 10298-10299, AAGARDA 10302, AAGARDA 10304-10306, AAGARDA 10308, AAGARDA 10310-10311, AAGARDA 10314, AAGARDA 10316-10317, AAGARDA 10345; Physalaemus albrifrons - MZFS 4845-4853, AAGARDA 10190-10191, AAGARDA 10255, AAGARDA 10258, AAGARDA 10405; Physalaemus cicada MZFS 4855-4864, AAGARDA 10332-10334, AAGARDA 10348, AAGARDA 10375, AAGARDA 10377-10381, AAGARDA 10397, AAGARDA 10406-10407; Physalaemus cuvieri-MZFS 4854, AAGARDA 10295; Pleurodema diplolister - MZFS 4892-4905, AAGARDA 10234-10238, AAGARDA 10349-10353, AAGARDA 10358-10359, AAGARDA 10362-10363; Pseudopaludicola pocoto - MZFS 4847-4848, MZFS 4865-4878, AAGARDA 10192-10197, AAGARDA 10199, AAGARDA 10201-10202, AAGARDA 10205-10207, AAGARDA 10385-10386, AAGARDA 10388-10389; Proceratophrys cristiceps - AAGARDA 10219, AAGARDA 10291,
AAGARDA 10396, AAGARDA 10398-10402; Rhinella granulosa - MZFS 4826-4840, AAGARDA 10214-10215, AAGARDA 10220-10221, AAGARDA 10223, AAGARDA 10225-10229, AAGARDA 10231-10233, AAGARDA 10337, AAGARDA 10366, AAGARDA 10410-10411; Rhinella jimi AAGARDA 10249, AAGARDA 10408-10409; Scinax x-signatus - MZFS 4802-4805, MZFS 4880-4891, AAGARDA 10239 , AAGARDA 10241, AAGARDA 10243, AAGARDA 10245, AAGARDA 10247-10248, AAGARDA 10279, AAGARDA 10324-10326, AAGARDA 10338, AAGARDA 10346, AAGARDA 10367-10371

\section{Acknowledgements}

We are grateful to the owners Mr. Alzir and Mr. Nogueira for access to their proprieties for field assistance. This work was funded by Sistema Nacional de Pesquisa em Biodiversidade SISBIOTA (CNPq \# 563075/2010-4, FAPESP \# 2010/52321-7), Programa de Pesquisa em Biodiversidade do Semiárido - PPBio/ CNPq (\# 558317/2009-0), and by a grant from CNPq/ICMBio (552031/2011-9) to AAG. MFN thanks the Conselho Nacional de Desenvolvimento Científico e Tecnológico (CNPq) for research productivity grant (Proc. 309672/2012-0).

\section{References}

AB'SÁBNER, A.N. 1977. Os domínios morfoclimáticos na América do Sul. Geomorfologia. 52:1-23.

AB'SÁBER, A.N. 2003. Os Domínios de Natureza no Brasil Potencialidades Paisagísticas. Ateliê Editorial, São Paulo.

ALBUQUERQUE U.P., ARAÚJO, E.L., EL-DEIR, A.C.A., LIMA, A.L.A., SOUTO, A., BEZERRA, B.M., FERRAZ, E.M.N., FREIRE, E.M.X., SAMPAIO, E.V.S.B., LAS-CASAS, F.M.G., MOURA, G.J.B., PEREIRA, G.A., MELO, J.G., RAMOS, M.A., RODAL, M.J.N., SCHIEL, N., LYRA-NEVES, R.M., ALVES, R.R.N., AZEVEDO-JÚNIOR, S.M., TELINO JÚNIOR, W.R \& SEVERI, W. 2012. Caatinga revisited: ecology and conser vation of an important seasonal dry forest. Sci. World J. 2012:1-18. http://dx.doi.org/10.1100/2012/205182 
ARZABE, C. 1999. Reproductive activity patterns of anurans in two different altitudinal sites within the Brazilian Caatinga. Rev. Bras. Zool. 16(3):851-864. http://www.scielo.br/scielo.php?pid =S0101 $81751999000300022 \&$ script $=$ sci_arttext, http://dx.doi.org/10.1590/ S0101-81751999000300022

BORGES-LEITE, M.J., RODRIGUES, J.F.M. \& BORGESNOJOSA, D.M. 2014. Herpetofauna of a coastal region of northeastern Brazil. Herpetol. Notes. 7:405-413. http://www. herpetologynotes.seh-herpetology.org/Volume7_PDFs/Borges_ HerpetologyNotes_volume7_pp405-413.pdf

BORGES-NOJOSA, D.M. 2007. Diversidade de Anfíbios e Répteis da Serra de Baturité, Ceará. In: Diversidade e Conservação da Biota na Serra de Baturité, Ceará (Oliveira, T.S \& Araújo, F.S., eds.). Edições UFC, Fortaleza, p.225-247.

BORGES-NOJOSA, D.M. \& CASCON, P. 2005. Herpetofauna da Área Reserva da Serra das Almas, Ceará. In Análise das Variações da Biodiversidade do Bioma Caatinga. (Araújo, F.S., Rodal, M.J.N., \& Barbosa, M.R.V., eds.). Ministério do Meio Ambiente, Brasília, p. $243-258$.

BORGES-NOJOSA, D.M., PRADO, F.M.V., BORGES-LEITE, M.J., GURGEL-FILHO, N.M. \& BACALINI, P. 2010. Avaliação do impacto do manejo florestal sustentável na herpetofauna de duas áreas de caatinga nos municípios de Caucaia e pacajus no Estado do Ceará. (Gariglio, M.A., Sampaio, E.V.S.B., Cestaro, L.A. \& Kageyama, P.Y. eds.). Serviço Florestal Brasileiro, Brasília, p. 315-330.

BORGES-NOJOSA, D. M. \& SANTOS, E M. 2005. Herpetofauna da Área de Betânia e Floresta, Pernambuco. In Análise das Variações da Biodiversidade do Bioma Caatinga. (Araújo, F.S., Rodal, M.J.N., \& Barbosa, M.R.V., eds.). Ministério do Meio Ambiente, Brasília, p. $277-291$

BRASIL. MINISTÉRIO DO MEIO AMBIENTE. INSTITUTO CHICO MENDES DE CONSERVAÇÃO DA BIODIVERSIDADE. 2014. Lista nacional oficial de espécies da fauna ameaçadas de extinção. Diário Oficial da união. 245:121-126.

CAMARDELLI, M. \& NAPOLI, M.F. 2012. Amphibian Conservation in the Caatinga Biome and Semiarid Region of Brazil. Herpetologica. 68:31-47. http://dx.doi.org/10.1655/HERPETOLO GICA-D-10-00033.1

CAVALCANTI, L.B.Q., COSTA, T.B., COLLI, G.R., COSTA, G.C., FRANÇA, F.G.R., MESQUITA, D.O., PALMEIRA, C.N.S., PELEGRIN, N., SOARES, A.H.B.S., TUCKER, D.B. \& GARDA, A.A. 2014. Herpetofauna of protected areas in the Caatinga II: Serra da Capivara National Park, Piauí, Brazil. Check List 10(1):18-27. http://www.checklist.org.br/getpdf?SL042-13, http://dx.doi.org/10.15560/10.1.18

GOTELLI, N.J. \& COLWELL, R.K. 2001. Quantifying biodiversity: procedures and pitfalls in the measurement and comparison of species richness. Ecol. Lett. 4:379-391. http://dx.doi.org/10.1046/j.14610248.2001.00230.x

HEYER, W.R., DONNELLY, M.A., MCDIARMID, R.W., HAYEK, L.A.C. \& FOSTER, M.S. 1994. Measuring and Monitoring Biological Diversity: Standard Methods for Amphibians. Biological Diversity Handbook Series. Stmithsonian Intitution Press. Washington.

INMET. Instituto Nacional de Meteorologia. www.inmet.gov.br (último acesso em 10/12/2014)

IUCN. The IUCN Red List of Threatened Species. Version 2014.3. www.iucnredlist.org. (último acesso em 10/12/2014)

KOTTEK, M., GRIESER, J., BECK, C., RUDOLF, B. \& RUBEL, F. 2006. World map of the Köppen-Geiger climate classification updated. Meteorol. Z. 15:259-263. http://dx.doi.org/10.1127/0941-2948/2006/0130

LEAL, I.R., TABARELLI, M. \& DA SILVA, J.M.C. 2003. Ecologia e conservação da Caatinga. Editora Universitária UFPE. Recife. http://www.mma.gov.br/estruturas/203/_arquivos/5_livro_ecologia_ e_conservao_da_caatinga_203.pdf
LOEBMANN, D. \& HADDAD, C.F.B. 2010. Amphibians and reptiles from a highly diverse area of the Caatinga domain: composition and conservation implications. Biota Neotropica. 10:227-256. http://dx.doi.org/10.1590/S1676-06032010000300026

MAGALHÃES, F.M., DANTAS, A.K.B.P., BRITO, M.R.M., MEDEIROS, P.H.S., OLIVEIRA, A.F., PEREIRA, T.C.S.O., QUEIROZ, M.H.C., SANTANA, D.J., SILVA, W.P. \& GARDA, A.A. 2013. Anurans from an Atlantic Forest-Caatinga ecotone in Rio Grande do Norte State, Brazil. Herpetol. Notes 6:1-10. http:// www.herpetologynotes.seh-herpetology.org/Volume6_PDFs/Magal haes_Herpetology_Notes_Volume6_page1-10.pdf

MAGALHÃES, F.M., LOEBMANN, D., KOKUBUM, M.N.C., HADDAD, C.F.B. \& GARDA, A.A. 2014. A New Species of Pseudopaludicola (Anura: Leptodactylidae: Leiuperinae) from Northeastern Brazil. Herpetologica 70:77-88. http://dx.doi.org/ 10.1655/HERPETOLOGICA-D-13-00054

MELO, F.P., SIQUEIRA, J.A., SANTOS, B.A., ÁlVARES-DASILVA, O., CEBALLOS, G. \& BERNARD, E. 2014. Football and Biodiversity Conservation: FIFA and Brazil Can Still Hit a Green Goal. Biotropica. 46(3):257-259. http://dx.doi.org/10.1111/btp.12114

MMA - Ministério do Meio Ambiente. 2007. Áreas prioritárias para conservação, uso sustentável e repartição de benefícios da biodiversidade brasileira. Ministério do Meio Ambiente, Secretaria de Biodiversidade e Florestas, Distrito Federal.

PROTÁZIO, A.S., ALBUQUERQUE, R.L., FALKENBERG, L.M. \& MESQUITA, D.O. 2014. Acoustic ecology of an anuran assemblage in the arid Caatinga of northeastern Brazil. J. Nat. Hist. 1-20. http://dx.doi.org/10.1080/00222933.2014.931482

RIBEIRO, S.C., ROBERTO, I.J., SALES, D.L., ÁVILA, R.W. \& ALMEIDA, W.O. 2012. Amphibians and reptiles from the Araripe bioregion, northeastern Brazil. Salamandra. 48(3):133-146. http:// www.salamandra-journal.com/index.php?option $=$ com_docman\& task $=$ doc_download\&gid $=292 \&$ Itemid $=74$

SANTOS, A.J. 2003. Estimativa de riqueza em espécies (Cullen-Jr, L., Rudran, R. \& Valladares-Padua, C. eds.). Editora da Univeraidade Federal do Paraná, Curitiba, p. 19-41.

SILVA, L.A., HOFFMANN, M.C. \& SANTANA, D.J. 2014. New record of Corythomantis greeningi Boulenger, 1896 (Amphibia, Hylidae) in the Cerrado domain, state of Tocantins, Central Brazil. Herpetol. Notes. 7:717-720. http://biotaxa.org/hn/article/view/7932

SOUSA, A.B. \& DA SILVA, D.F. 2013. Avaliação climática e dos recursos hídricos da bacia hidrográfica do Rio Jaguaribe. Rev. Bras. Geo. Fís. 6:1115-1140. http://www.revista.ufpe.br/rbgfe/ index.php/revista/article/viewArticle/749

TABARELLI, M., SILVA, J.M.C. \& LEAL, I.R. 2003. Áreas e ações prioritárias para a conservação da biodiversidade da Caatinga (Leal, I.R., Silva J.M.C. \& Tabarelli, M. eds.). Editora Universitária UFPE. Recife, p. 777-796.

TEIXEIRA-JR, M., AMARO, R.C., RECODER, R.S., DAL VECHIO, F \& RODRIGUES, M.T. 2012. A new dwarf species of Proceratophrys Miranda-Ribeiro, 1920 (Anura, Cycloramphidae) from the highlands of Chapada Diamantina, Bahia, Brazil. Zootaxa. 3551:25-42. http://www. mapress.com/zootaxa/2012/f/z03551p042f.pdf

VIEIRA, W.L.S., ARZABE, C. \& SANTANA, G.G. 2007. Composição e distribuição espaço-temporal de anuros no Cariri paraibano, Nordeste do Brasil. Oecol. Brasil. 11(3): 383-396. http:// www.oecologiaaustralis.org/ojs/index.php/oa/article/viewFile/198/125, http://dx.doi.org/10.4257/oeco

WELLS, K.D. 1977. The social behaviour of anuran amphibians. Anim. Behav. 25:666-693. http://dx.doi.org/10.1016/0003-3472(77)90118-X

XAVIER, A.L., NAPOLI, M.F. 2011. Contribution of environmental variables to anuran community structure in the Caatinga Domain of Brazil. Phyllomedusa. 10(1): 45-64. http://dx.doi.org/10.11606/ issn.2316-9079.v10ilp45-64 